\title{
THE ASSAY AND PROPERTIES OF LABILE FACTOR (FACTOR V)
}

\author{
BY \\ ARMAND J. QUICK*
From the Department of Biochemistry, Marquette University School of Medicine, Milwaukee, Wisconsin
}

(RECEIVED FOR PUBLICATION SEPTEMBER 9, 1960)

\begin{abstract}
Human oxalated plasma stored at $4^{\circ} \mathrm{C}$. until the prothrombin time is increased beyond 60 sec. is a reliable medium for assaying labile factor (factor $V$ ) because its response to added labile factor corresponds quantitatively to that of plasma from patients with congenital deficiency of this factor. Such an agreement is not obtained with plasma stored at $37^{\circ} \mathrm{C}$. The stability of labile factor is closely associated with ionized calcium. The addition of thrombin to fresh oxalated plasma causes an apparent hyperactivity of labile factor, but this is completely removed by adsorption with $\mathrm{Ca}_{3}(\mathrm{PO})_{2}$. Oxalated plasma when adsorbed with $\mathrm{Ca}_{3}\left(\mathrm{PO}_{4}\right)_{2}$ before treatment with thrombin does not develop this adventitious activity, nor does it occur in stored plasma treated with thrombin. The seemingly high labile factor activity in serum can be explained by the activation of this factor which is independent of labile factor but acts synergistically with it. The true labile factor concentration can be determined only after the accelerator is removed by adsorption with $\mathrm{Ca}_{3}\left(\mathrm{PO}_{4}\right)_{2}$. A close agreement between the consumption of prothrombin and the loss of labile factor during clotting is observed.
\end{abstract}

The discovery in 1943 of a new clotting factor now commonly known as labile factor or factor $\mathrm{V}$, which was not recognized in the classical theory of blood coagulation formulated by Morawitz in 1904 , initiated a radically new approach to the study of coagulation mechanisms and the haemorrhagic diseases. Owren (1947a) described the first case in which a bleeding state was caused by lack of a factor which appeared to be similar or identical with the one which is decreased when oxalated human plasma is stored at $4^{\circ} \mathrm{C}$. On the assumption that the prolonged prothrombin time of such stored plasma is caused specifically by a loss of labile factor, a method of assay using a stored human plasma as the medium was developed by Quick and Stefanini (1948). With this procedure, it was shown that human blood contains a much lower concentration of labile factor than the blood of the common laboratory animals. Since there had been no opportunity to compare stored plasma directly with that from a patient with congenital deficiency of labile factor, the unequivocal reliability of the assay method could not be established. With the availability recently of blood from three siblings having strikingly low concentrations of labile factor, such a comparative study

*This work was supported by the American Heart Association. could be made, and it prompted a reinvestigation of this clotting factor.

\section{Material and Methods}

Collection of Blood.-A silicone-coated needle and syringe were used and the blood was transferred to test-tubes similarly coated. These were kept in an ice bath until used.

One-stage Prothrombin Time.-The exact procedure as previously described (Quick, 1957) was followed. This included using sodium oxalate as the anticoagulant, acetone-dehydrated rabbit brain as the thromboplastin reagent, and $0.01 \mathrm{M} \mathrm{CaCl} 2$ for recalcification. A prothrombin time of $12 \mathrm{sec}$. for fresh normal human plasma was mandatory in the control for each experiment.

Adsorption of Plasma to Remove Prothrombin and Stable Factor (Factor VII). - One millilitre of a suspension of $0.012 \mathrm{M} \mathrm{Ca}\left(\mathrm{PO}_{4}\right)_{2}$ contains the correct amount of adsorbent to remove completely the prothrombin and stable factor (factor VII) from $1 \mathrm{ml}$. of oxalated rabbit plasma. The required volume of the suspension is pipetted into a test-tube and the $\mathrm{Ca}_{3}\left(\mathrm{PO}_{4}\right)_{2}$ is packed by centrifugation. The supernatant water is poured off, and after the tube is drained the plasma is added and mixed with the $\mathrm{Ca}_{3}\left(\mathrm{PO}_{4}\right)_{2}$. After five minutes the adsorbent is removed by high centrifugation. 


\section{Results}

\section{Comparison of Stored Human Plasma with} Plasma from Subjects Having Congenital Deficiency of Labile Factor.-On adding an equal volume of fresh normal oxalated plasma either to plasma from a patient with congenital deficiency of labile factor or to stored plasma, a mixture is obtained which has approximately a normal prothrombin time $\left(11 \frac{1}{2}-13 \mathrm{sec}\right.$.) (Table I). No correction is obtained when labile-factor-

\section{TABLE I}

COMPARISON OF PLASMA FROM PATIENTS HAVING CONGENITAL LABILE FACTOR DEFICIENCY WITH STORED PLASMA IN THE RESPONSE TO ADDED LABILE FACTOR

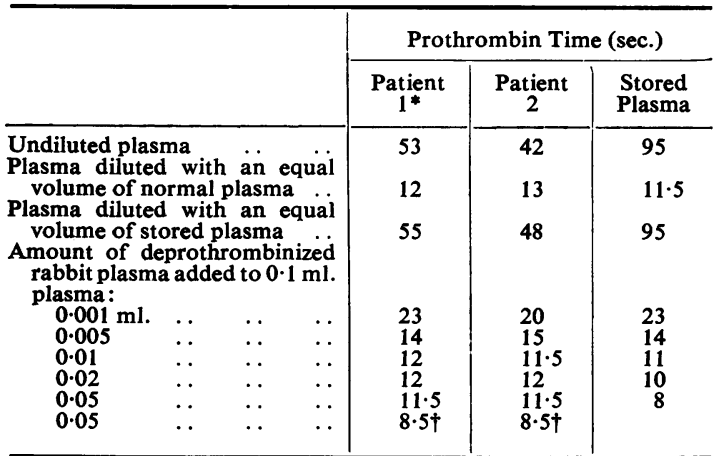

* The basic prothrombin consumption time of Patient 1 was 10.5 sec. When $0.1 \mathrm{ml}$. of deprothrombinized rabbit plasma was added to $1 \mathrm{ml}$. of the patient's blood before clotting, the prothrombin consumption time was $45 \mathrm{sec}$.

$\dagger$ After 48 hours' storage in glass.

deficient plasma is mixed with stored plasma. On adding fixed amounts of deprothrombinized rabbit plasma, which has a high concentration of labile factor, to the patient's plasma and to stored plasma, the correction of the prothrombin time is quantitatively the same in both types of plasma except that, with increasing amounts, a minimum prothrombin time of $8 \mathrm{sec}$. is obtained in stored plasma and $11 \frac{1}{2} \mathrm{sec}$. in the patient's fresh plasma. When the patient's plasma is stored for 48 hours in glass at $4^{\circ} \mathrm{C}$., a minimum prothrombin time of $8 \frac{1}{2} \mathrm{sec}$. is then obtained. A probable explanation for this will be offered in the discussion.

The results in Table I show that normal plasma stored at $4^{\circ} \mathrm{C}$. appears to be nearly identical to plasma from patients with congenital labile factor deficiency. The ease with which labile factor can be diminished by storage at $4^{\circ} \mathrm{C}$. makes the preparation of plasma suitable for assaying labile factor very simple.

The method of Wolf (1953) for preparing plasma for assaying labile factor was found unsatisfactory. He incubates oxalated plasma at $37^{\circ} \mathrm{C}$. for 24 hours. From the results presented in Table II, it
TABLE II

COMPARISON OF HUMAN OXALATED PLASMAS STORED AT $4^{\circ}$ C. FOR 14 DAYS AND AT $37^{\circ}$ C. FOR 24 HOURS IN RESPONSE TO ADDED LABILE FACTOR

\begin{tabular}{|c|c|c|c|}
\hline & \multicolumn{3}{|c|}{ Prothrombin Time (sec.) } \\
\hline & Fresh & $\begin{array}{l}\text { Stored at } \\
4^{\circ} \text { C. for } \\
14 \text { Days }\end{array}$ & $\begin{array}{l}\text { Stored at } \\
37^{\circ} \text { C. for } \\
24 \text { Hours }\end{array}$ \\
\hline 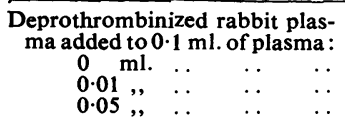 & $\begin{array}{l}12 \\
12 \\
11\end{array}$ & $\begin{array}{r}60 \\
10 \\
8\end{array}$ & $\begin{array}{r}240 \\
50 \\
18\end{array}$ \\
\hline
\end{tabular}

is evident that changes other than loss of labile factor occur in the plasma, so that the addition of excess labile factor does not bring the prothrombin time to normal as it will when added to plasma stored at $4^{\circ} \mathrm{C}$.

Assay Method for Labile Factor.-Normal oxalated plasma is distributed in $5 \mathrm{ml}$. portions to test-tubes which are placed in a refrigerator kept at $4^{\circ} \mathrm{C}$. The prothrombin time is determined after seven days, and again at several days' intervals, until it has increased to $60 \mathrm{sec}$. This requires about a fortnight. The plasmas are pooled and stored at $-20^{\circ} \mathrm{C}$.

The labile factor curve is based on the finding that when 1 vol. of fresh human plasma is mixed with 9 vol. of stored plasma, the mixture has a prothrombin time which averages about $18 \mathrm{sec}$. The usual range is 17 to $20 \mathrm{sec}$. A plasma giving a correction of $18 \mathrm{sec}$. is arbitrarily designated as having a labile factor concentration of 100 , and, since 1 vol. of this plasma is mixed with 9 vol. of stored plasma which has a concentration of less than $1 \%$, the $18 \mathrm{sec}$ can be regarded as the

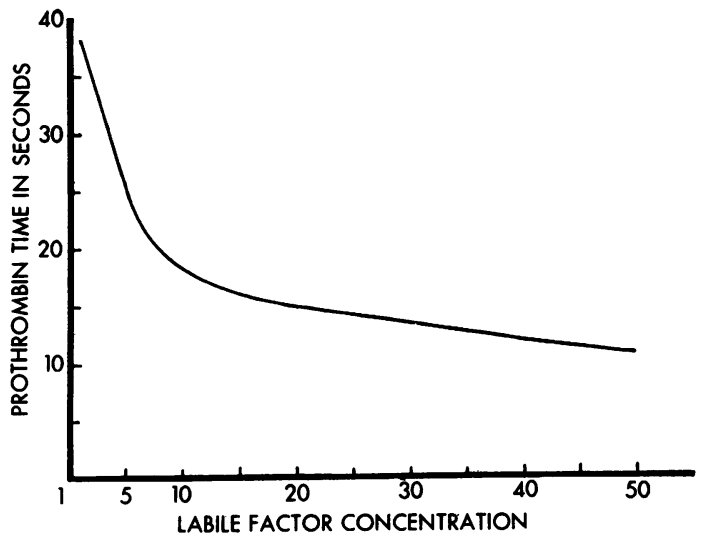

FIG. 1.-The relation of the prothrombin time to the concentration of labile factor (factor $V$ ) in human plasma. The concentration of labile factor was calculated from the dilution of fresh norma plasma with aged plasma. 
prothrombin time of a plasma containing $10 \%$ of labile factor. By means of varying dilutions of stored plasma with fresh, values are obtained from which a curve can be constructed correlating the prothrombin time with labile factor deficiency (Fig. 1). It will be noted that the prothrombin time becomes $12 \mathrm{sec}$. when $4 \mathrm{vol}$. of fresh plasma is mixed with 6 vol. of stored plasma. Fresh plasma contains over twice as much labile factor as is required to maintain the prothrombin time at $12 \mathrm{sec}$; ; consequently, over half can be lost before the prothrombin time is prolonged.

In carrying out the test, the plasma to be assayed is adsorbed with $\mathrm{Ca}_{3}\left(\mathrm{PO}_{4}\right)_{2}$ at $4^{\circ} \mathrm{C}$. This removes very little labile factor, but it does take out an accelerator which may be present. One-hundedth of a millilitre of the adsorbed plasma is mixed with $0.09 \mathrm{ml}$. of stored human plasma and the prothrombin time of the mixture determined. The value in terms of percentage of labile factor is read from the chart and multiplied by 10 because of the dilution.

The assay method is sensitive to small changes in labile factor even in the range before the prothrombin time is affected. This is illustrated by the simple experiment of incubating oxalated human plasma for $30 \mathrm{~min}$. at $37^{\circ} \mathrm{C}$. Owren (1947b) states that no deterioration of factor $\mathrm{V}$ occurs in this short period, yet when studied by our method (Table III) it is found that the activity decreased from $120 \%$ to $86 \%$, which is a drop of $28 \%$.

Concentration of Labile Factor in Various Laboratory Animals. - The determination of labile
TABLE III

EFFECT OF INCUBATING OXALATED PLASMA AT $37^{\circ} \mathrm{C}$. ON LABILE FACTOR

\begin{tabular}{|c|c|c|c|c|}
\hline & & \multicolumn{2}{|c|}{ Prothrombin Time (sec.) } & \multirow{2}{*}{$\begin{array}{l}\text { Labile } \\
\text { Factor } \\
(\%)\end{array}$} \\
\hline & & Basic & $\begin{array}{l}\text { Mixed with } \\
9 \text { Vol. of } \\
\text { Aged Plasma }\end{array}$ & \\
\hline $\begin{array}{l}\text { Before incubation } \\
\text { After } 30 \text { min. incubation } \\
\text {," } 120, \text {, }\end{array}$ & $\begin{array}{l}\cdots \\
\cdots \\
\cdots\end{array}$ & $\begin{array}{l}12 \\
12 \\
17\end{array}$ & $\begin{array}{l}17 \\
19 \\
30\end{array}$ & $\begin{array}{r}120 \\
86 \\
29\end{array}$ \\
\hline
\end{tabular}

factur in the blood of the common laboratory animals is simple because the concentration is much higher than in human plasma. One need only determine how much the plasma has to be diluted to correct the prothrombin time of stored human plasma to $18 \mathrm{sec}$., which has been set as the normal correction when 1 vol. of fresh human plasma is mixed with 9 vol. of stored plasma. In determining the labile factor, the animal plasma is diluted with saline in various proportions. To $0.09 \mathrm{ml}$. of stored plasma, $0.01 \mathrm{ml}$. of the diluted plasma is added and the prothrombin time determined. From the prothrombin time obtained, the concentration of labile factor is calculated. The outstanding finding is the high concentration of labile factor in rabbit plasma and the low level in human plasma (Table IV).

\section{TABLE IV}

RELATIVE CONCENTRATION OF LABILE FACTOR (FACTOR V) IN PLASMA OF VARIOUS SPECIES

\begin{tabular}{c|c|c|c|c|c}
\hline Man & Rabbit & Dog & Cat & Cow & Sheep \\
\hline 100 & 5,000 & 1,000 & $350-500$ & 800 & $300-500$ \\
\hline
\end{tabular}

TABLE V

EFFECT OF YARIOUS ANTICOAGULANTS ON PROTHROMBIN TIME AND LABILE FACTOR DURING STORAGE AT $4^{\circ} \mathrm{C}$.

\begin{tabular}{|c|c|c|c|c|c|c|c|c|c|c|}
\hline & & & & \multirow{3}{*}{$\begin{array}{c}\text { Time of } \\
\text { Storage } \\
\text { (hr.) }\end{array}$} & \multicolumn{6}{|c|}{ Prothrombin Time } \\
\hline \multirow{2}{*}{\multicolumn{4}{|c|}{ Anticoagulant }} & & \multicolumn{3}{|c|}{ In Glass } & \multicolumn{3}{|c|}{ In Silicone } \\
\hline & & & & & $\begin{array}{l}\text { Basic } \\
(\mathrm{sec} .)\end{array}$ & $\begin{array}{c}\text { Corrected } \\
\text { for Labile } \\
\text { Factor* } \\
\text { (sec.) }\end{array}$ & $\begin{array}{c}\text { Mixed with } \\
9 \text { Vol. } \\
\text { Aged Plasma† } \\
\text { (sec.) }\end{array}$ & $\begin{array}{l}\text { Basic } \\
\text { (sec.) }\end{array}$ & $\begin{array}{c}\text { Corrected } \\
\text { for Labile } \\
\text { Factor* } \\
\text { (sec.) }\end{array}$ & $\begin{array}{c}\text { Mixed with } \\
9 \text { Vol. } \\
\text { Aged Plasma† } \\
\text { (sec.) }\end{array}$ \\
\hline \multicolumn{4}{|c|}{ Sodium oxalate $0 \cdot 1 \mathrm{M}$} & $\begin{array}{r}0 \\
24 \\
48\end{array}$ & $\begin{array}{l}12 \\
14 \\
20\end{array}$ & $\begin{array}{l}12 \\
8 \cdot 5 \\
8\end{array}$ & $\begin{array}{l}17 \\
29 \\
41\end{array}$ & $\begin{array}{l}12 \\
16 \cdot 5 \\
23\end{array}$ & $\begin{array}{l}12 \\
12 \\
12\end{array}$ & $\begin{array}{l}17 \\
26 \\
36\end{array}$ \\
\hline \multicolumn{4}{|c|}{ citrate $0 \cdot 1 \mathrm{M}$} & $\begin{array}{r}0 \\
24 \\
48\end{array}$ & $\begin{array}{c}12 \\
9 \\
10 \cdot 5\end{array}$ & $\begin{array}{l}12 \\
8 \\
8 \cdot 5\end{array}$ & $\begin{array}{l}17 \\
18 \\
20\end{array}$ & $\begin{array}{l}12 \\
12 \\
13\end{array}$ & $\begin{array}{l}11 \\
12 \\
11\end{array}$ & $\begin{array}{l}17 \\
18 \\
17 \cdot 5\end{array}$ \\
\hline$"$ & $"$ & $0.2 \mathrm{M}$ & .. & $\begin{array}{r}0 \\
24 \\
48\end{array}$ & $\begin{array}{l}12 \\
13 \\
16\end{array}$ & $\begin{array}{l}12 \\
8 \cdot 5 \\
9\end{array}$ & $\begin{array}{l}17 \\
21 \\
25\end{array}$ & $\begin{array}{l}12 \\
14.5 \\
17.5\end{array}$ & $\begin{array}{l}12 \\
12 \\
12\end{array}$ & $\begin{array}{l}17 \cdot 5 \\
20 \cdot 5 \\
24\end{array}$ \\
\hline None & . & . & .. & $\begin{array}{r}0 \\
24 \\
48\end{array}$ & & & & $\begin{array}{l}12 \\
12 \\
12\end{array}$ & $\begin{array}{l}11 \\
11 \\
11 \cdot 5\end{array}$ & $\begin{array}{l}17 \\
16 \cdot 5 \\
17\end{array}$ \\
\hline
\end{tabular}

* To $0.09 \mathrm{ml}$. of the plasma, $0.01 \mathrm{ml}$. of deprothrombinized rabbit plasma was added. † To $0.09 \mathrm{ml}$. of aged plasma, $0.01 \mathrm{ml} .0 \mathrm{f}$ the plasma studied was added. 
Effect of Anticoagulants on Labile Factor in Plasma Stored at $4^{\circ}$ C.-Three types of plasma were studied: oxalated, citrated, and native. The results are recorded in Table $\mathrm{V}$. The decrease of labile factor is greatest in oxalated plasma, but it is also fairly rapid when plasma is mixed with $0.2 \mathrm{M}$ sodium citrate. With $0.1 \mathrm{M}$ sodium citrate, the loss of labile factor is greatly retarded and in native plasma is almost negligible in the first 48 hours. The decrease of labile factor is not significantly different in glass or silicone-coated containers, but the prothrombin activity as measured by the prothrombin time after adding an excess of labile factor is increased in glass but remains practically unchanged in silicone.

Concentration of Labile Factor in Serum.When human blood is clotted in glass, the resulting serum appears to have a higher labile factor activity than does the corresponding oxalated plasma as shown in Table VI. When the serum

TABLE VI

LABILE FACTOR ACTIVITY IN SERUM

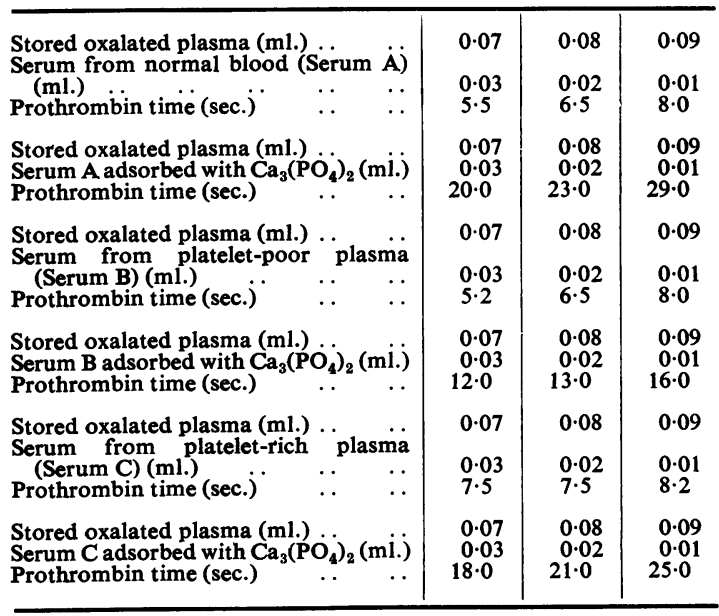

is adsorbed with $\mathrm{Ca}_{3}\left(\mathrm{PO}_{4}\right)_{2}$, this hyperactivity is lost and the concentration of labile factor is found actually to be low, suggesting that much of this factor is consumed during clotting. If plateletpoor plasma is clotted, the resulting serum also shows the apparent hyperactivity, which, after adsorption, is lost, but the residual concentration of labile factor is higher than in the serum obtained from the clotting of whole blood or platelet-rich plasma.

Action of Thrombin on Labile Factor in Oxalated Plasma.-When thrombin is added to oxalated plasma, the resulting defibrinated product has, like serum, a distinct hyperactivity when tested
TABLE VII

EFFECT OF THROMBIN ON LABILE FACTOR ACTIVITY

\begin{tabular}{|c|c|c|c|}
\hline $\begin{array}{l}\text { Stored oxalated plasma (ml.) .. } \\
\text { Fresh oxalated plasma (Plasma A) (mi.) } \\
\text { Prothrombin time (sec.) }\end{array}$ & $\begin{array}{r}0 \cdot 07 \\
0 \cdot 03 \\
12 \cdot 2\end{array}$ & $\begin{array}{l}0.08 \\
0.02 \\
13.5\end{array}$ & $\begin{array}{r}0.09 \\
0.01 \\
17.5\end{array}$ \\
\hline Stored oxalated plasma (ml.) ... ... & 0.07 & 0.08 & 0.09 \\
\hline 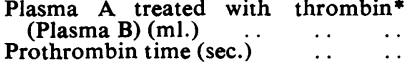 & $\begin{array}{l}0.03 \\
9 \cdot 0\end{array}$ & $\begin{array}{c}0.02 \\
10 \cdot 0\end{array}$ & $\begin{array}{r}0.01 \\
11 \cdot 0\end{array}$ \\
\hline $\begin{array}{l}\text { Stored oxalated plasma }(\mathrm{ml}) \\
\text { Plasma B adsorbed with } \mathrm{Ca}_{3}\left(\mathrm{PO}_{4}\right)_{2}(\mathrm{ml} .) \\
\text { Prothrombin time (sec.) }\end{array}$ & $\begin{array}{l}0.07 \\
0.03 \\
15 \cdot 0\end{array}$ & $\begin{array}{l}0.08 \\
0 \cdot 02 \\
19 \cdot 0\end{array}$ & $\begin{array}{r}0.09 \\
0.01 \\
22.0\end{array}$ \\
\hline Stored oxalated plasma (ml.) & 0.07 & 0.08 & 0.09 \\
\hline 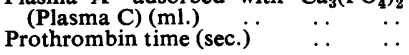 & $\begin{array}{l}0.03 \\
13 \cdot 0\end{array}$ & $\begin{array}{l}0 \cdot 02 \\
16 \cdot 0\end{array}$ & $\begin{array}{l}0 \cdot 01 \\
18 \cdot 5\end{array}$ \\
\hline $\begin{array}{l}\text { Stored oxalated plasma (ml.) } \\
\text { Plasma C treated with thrombin* (mi.) } \\
\text { Prothrombin time (sec.) }\end{array}$ & $\begin{array}{l}0.07 \\
0.03 \\
12 \cdot 5\end{array}$ & $\begin{array}{c}0.08 \\
0.02 \\
14 \cdot 5\end{array}$ & $\begin{array}{r}0.09 \\
0 \cdot 01 \\
17 \cdot 0\end{array}$ \\
\hline Stored oxalated plasma (ml.) ... & 0.07 & 0.08 & 0.09 \\
\hline $\begin{array}{l}\text { Stored plasma treated with thromoin } \\
\text { (ml.) } \ldots \\
\text { Prothrombin time (sec.) }\end{array}$ & $\begin{array}{l}0 \cdot 03 \\
48 \cdot 0\end{array}$ & $\begin{array}{l}0 \cdot 02 \\
47 \cdot 5\end{array}$ & $\begin{array}{r}0.01 \\
44 \cdot 0\end{array}$ \\
\hline
\end{tabular}

* Five units of thrombin were added to $1 \mathrm{ml}$. of plasma. The defibrinated plasma was kept at $4^{\circ} \mathrm{C}$. for one hour before testing.

on stored plasma (Table VII), but adsorption with $\mathrm{Ca}_{3}\left(\mathrm{PO}_{4}\right)_{2}$ removes this increased activity. When oxalated plasma is adsorbed with $\mathrm{Ca}_{3}\left(\mathrm{PO}_{4}\right)_{2}$ before the addition of thrombin, no adventitious activity develops : likewise, in stored oxalated plasma, this activity fails to develop on treatment with thrombin.

\section{Discussion}

The observation of various investigators that in congenital deficiency of labile factor the other plasma constituents which influence the prothrombin time are normal suggests that the plasma from such patients should be ideal for assaying the factor. It has, however, the disadvantage of not being readily available. The finding that normal plasma stored at $4^{\circ} \mathrm{C}$. can be reliably substituted makes the quantitative study of labile factor possible and easy for any clinical laboratory.

The concentration of labile factor in human blood is much lower than in the common laboratory animals. This observation, which was made in the original study (Quick, 1943), has been confirmed by Murphy and Seegers (1948) and by Didisheim, Hattori, and Lewis (1959). The suggestion of Murphy and Seegers that the low level in man may "offer at least a partial explanation for the reported discrepancy of prothrombin values obtained by the one-stage and two-stage methods" is not supported experimentally. The concentration of labile factor in normal human plasma is not the limiting factor that fixes the prothrombin time (Quick, 1958). Over one-half of the labile factor must be lost before the 
prothrombin time becomes prolonged as is shown in this study and was earlier reported by Alexander and DeVries (1949).

Confusion still exists concerning the stability and alteration of activity of labile factor. It was originally observed (Quick, 1943) that native chicken and goose plasma showed no increase of prothrombin time kept seven days in a refrigerator. When these plasmas were oxalated, the prothrombin time became markedly prolonged on storage. This suggests that the stability of labile factor is decreased in the absence of ionized calcium. In the present study it is shown that native human plasma loses little labile factor on storage in 48 hours, whereas the oxalated plasma does. Significantly, when 9 vol. of plasma is mixed with 1 vol. of $0.1 \mathrm{M}$ sodium citrate, the resulting mixture exhibits no increase in the prothrombin time; it actually shows a decrease. If, instead, $0.2 \mathrm{M}$ citrate is used, the same increase in prothrombin time is observed as in oxalated plasma. The difference in stability of labile factor in citrated and oxalated plasma was observed by Fahey, Ware, and Seegers (1948), but they offered no explanation. Since $0.1 \mathrm{M}$ sodium citrate does not completely depress the ionized calcium, it seems justifiable to conclude that the greater stability of the labile factor in the weaker citrate plasma is due to ionized calcium which is not completely depressed (Hussey, Quick, Stefanini, Consolazio, and Sargent, 1950).

When blood citrated with $0.1 \mathrm{M}$ citrate is stored in glass at $4^{\circ} \mathrm{C}$., the prothrombin time decreases from the initial $12 \mathrm{sec}$. to about 9 sec., whereas no change occurs when stored in silicone. It is further observed that both the oxalated and citrated plasmas stored in glass have prothrombin times of 8 to $9 \mathrm{sec}$. when excess labile factor is added, but the same plasmas kept in silicone-coated test-tubes retain a prothrombin time of approximately $12 \mathrm{sec}$. Alexander and DeVries also noted this enhanced prothrombin activity on storage in glass and remarked that it could not be explained. Shortly before this, Quick and Stefanini (1949) formulated the hypothesis that the prothrombin in human blood is only partly free and that a large fraction is in an inactive state. On storage in glass the inactive prothrombin becomes activated, whereupon the prothrombin time is shortened. In both oxalated and citrated plasma this activation readily occurs in glass but not in silicone. Since the rate at which labile factor decreases in oxalated and in $0.2 \mathrm{M}$ sodium citrated plasmas is much greater than the speed of activation of prothrombinogen, the prothrombin time steadily increases. In the plasma with $0.1 \mathrm{M}$ sodium citrate, the reverse is true because the rate with which labile factor disappears is much slower than that of the activation of inactive prothrombin.

During storage of adult human plasma in glass at $4^{\circ} \mathrm{C}$., two changes are occurring simultaneously : labile factor is diminishing and, according to the author's hypothesis, inactive prothrombin is being converted to the active form. The latter reaction, which is measurable by the one-stage prothrombin time, is masked unless the first is retarded, as occurs when plasma is mixed with $0.1 \mathrm{M}$ sodium citrate. These changes occur in the absence of thrombin. When oxalated plasma is treated with thrombin and incubated for one hour to permit inactivation of the added thrombin, the resulting defibrinated plasma has, when tested by our assay method, shown a marked increase in what appears to be labile factor activity. When, however, the defibrinated plasma is treated with $\mathrm{Ca}_{3}\left(\mathrm{PO}_{4}\right)_{2}$, this hyperactivity is lost and the adsorbed plasma is found to have a slightly lower concentration of labile factor than it had before treatment with thrombin. This clearly suggests that thrombin brings about the generation of another factor which acts synergistically with labile factor to shorten the prothrombin time markedly. If oxalated plasma is adsorbed with $\mathrm{Ca}_{3}\left(\mathrm{PO}_{4}\right)_{2}$ before treatment with thrombin, no hyperactivity develops. Likewise, thrombin fails to produce this adventitious activity in stored plasma. This factor which is activated by thrombin appears to be distinct and independent of labile factor. It is adsorbed by $\mathrm{Ca}_{3}\left(\mathrm{PO}_{4}\right)_{2}$ and is absent in stored plasma. It is probably identical with the agent Alexander, DeVries, Goldstein, and Landwehr (1949) named S.P.C.A. (serum prothrombin conversion accelerator).

The activation of this new factor explains the apparently high labile factor activity in serum. When, however, the serum is adsorbed with $\mathrm{Ca}_{3}\left(\mathrm{PO}_{4}\right)_{2}$, it is found that the labile factor has actually diminished. The more complete the clotting as measured by the prothrombin consumption test, the greater the decrease of labile factor, and conversely in defective clotting, such as occurs in haemophilia and thrombocytopenia, much labile factor remains in the serum. This was reported by Alexander, Goldstein, and Landwehr (1950) and again recently by Douglas (1956).

These observations suggest that labile factor enters the reaction as a reactant and not as an accelerator. At the time Fahey et al. (1948) carried out their studies on the factor which they called Ac-globulin, the S.P.C.A. of Alexander had not been recognized. The observation of greater 
activity in serum was regarded as an activation of Ac-globulin; they distinguished between plasma Ac-globulin and serum Ac-globulin and postulated that the factor existed in plasma in an inactive state, probably as a proenzyme. Owren (1951) has also accepted the view that the factor is in a precursor state and has designated it proaccelerin. As Alexander et al. (1950) pointed out, the activity which is called serum Ac-globulin (and one can also include Owren's accelerin) is in all probability a mixture of plasma Ac-globulin or labile factor with S.P.C.A. The hypothesis that labile factor exists in blood in a precursor state and that when activated it becomes an accelerator is based on experimental observations which require reinterpretation.

The probable place at which labile factor enters the coagulation reaction was investigated by Quick and Stefanini (1950). They observed that little or no prothrombin consumption occurs when tissue thromboplastin (rabbit brain extract) is added to recalcified stored plasma, but that the addition of increasing amounts of labile factor to this system brought about corresponding increments of prothrombin consumption. This indicated that labile factor acts stoichiometrically and is essential in the utilization of extrinsic thromboplastin. Our observation that prothrombin consumption is very low in a patient with congenital deficiency of labile factor shows that the factor is also essential for the utilization of intrinsic thromboplastin. It can be concluded that labile factor enters at a late stage of the clotting reaction. It actually appears to be a thromboplastin co-factor, a term which Honorato (1947) suggested. Douglas (1956) has also concluded that the factor enters at a stage later than antihaemophilic globulin, Christmas factor, and platelets.

This study was made possible through the kind co-operation of Dr. Irving Friedman, Hektoen Institute, Cook County Hospital, Chicago, Illinois. I wish to thank him for the opportunity of studying his patients with severe labile factor deficiency.

\section{REFERENCES}

Alexander, B., and DeVries, A. (1949). J. clin. Invest., 28, 24.

- Goldstein, R., and Landwehr, G. (1949). Science, 109, 545. Goldstein, R., and Landwehr, G. (1950). J.clin. Invest., 29, 881.

Didisheim, P., Hattori, K., and Lewis, J. H. (1959). J. Lab. clin. Med., 53, 866.

Douglas, A. S. (1956). Brit. J. Haemat., 2, 153.

Fahey, J. L., Ware, A. G., and Seegers, W. H. (1948). Amer. J. Physiol., 154, 122.

Honorato, R. (1947). Ibid., 150, 381.

Hussey, C. V., Quick, A. J., Stefanini, M., Consolazio, C. F., and Sargent, F. (1950). J. biol. Chem., 184, 105.

Murphy, R. C., and Seegers, W. H. (1948). Amer. J. Physiol., 154, 134.

Owren, P. A. (1947a). Lancet, 1, 446.

- (1947b). Acta med. scand., Suppl. 194.

- (1951). The Prothrombin Activating Complex and Its Clinical Significance. In Proc. III int. Congress of International Society음 of Hematology, Cambridge, 1950, pp. 379-396.

Quick, A. J. (1943). Amer. J. Physiol., 140, 212.

(1957). Hemorrhagic Diseases. Lea and Febiger, Philadelphia.

- (1958). Thromb. Diath. haemorrh. (Stuttg.), 2, 226.

— and Stefanini, M. (1948). J. Lab. clin. Med., 33, 819.

—— (1949). Ibid., 34, 973.

___ (1950). Amer. J. Physiol., 160, 572.

Wolf, P. (1953). J.clin. Path., 6, 34. 